\title{
PENGATURAN REKAPITALISASI PERSEROAN TERBATAS ${ }^{1}$
}

Oleh :

Gde Andika Sumadi ${ }^{2}$

\begin{abstract}
In the case of shortage of capital, limited liabililty company allowed to conduct recapitalization, an activity to increase capital. Recapitalization provisions set out in article 41 up to article 43 of Law No. 40 of 2007 does not comply with the basic considerations point $c$ of the limited liability company law. The provisions essentially determines the recapitalization can be carried out with the approval of the general meeting of shareholders that is based on the principle of one share one vote, while the considerations stated that the limited liability company is one pilar to accelerate national development that composed based on the principle of togetherness. The legal problems addressed in this study are first: how the recapitalization arrangements in the Law No. 40 of 2007?; second: how the ideal mechanism of recapitalization in realizing the the principle of togetherness within the limited liability company? This study is a normative legal research on arrangement of a limited liability company's recapitalization. The legal problem solving uses the statute approach and historical approach. The result of this study showed that the first, arrangements of recapitalization of the limited liability company law is inadequate because it creates a disadvantage for minority shareholders and not in accordance with the principle of togetherness which is exist on the considerations part of the limited liability company law. Second, the ideal mechanism of recapitalization is to use deliberation to reach an agreement and general meeting of shareholders not use the voting system which is more favorable to the majority shareholder. Shareholders of both majority and minority can make a contract that the recapitalization can be done without harming minority shareholders, for example by bonus shares.
\end{abstract}

Keywords : legal arrengements, recapitalization, limited liability company.

\begin{abstract}
Abstrak
Dalam menjalankan usahanya ada kalanya Perseroan Terbatas (PT) dihadapkan pada suatu situasi dimana PT mengalami kekurangan modal. Pada situasi seperti ini perseroan diberikan jalan untuk melakukan Rekapitalisasi atau penambahan modal yang diatur dalam Pasal 41-43 Undang-Undang No. 40 Tahun 2007 tentang Perseroan Terbatas (UUPT). Dalam ketentuan mengenai Rekapitalisasi ini terjadi konflik norma antara ketentuan yang mewajibkan rekapitalisasi atau penambahan modal dalam Perseroan dilaksanakan melalui persetujuan RUPS dengan bagian menimbang huruf c UUPT yang di dalamnya disebutkan bahwa PT merupakan

\footnotetext{
1 Artikel ini merupakan karya ilmiah mahasiswa pada Program Studi Magister (S2) Ilmu Hukum Program Pascasarjana Universitas Udayana serta mengucapkan terimakasih kepada Prof. Dr. Ida Bagus Wyasa Putra, SH.,M.Hum dan Dr. Putu Tuni Cakabawa Landra, SH.,M.Hum selaku Pembimbing Tesis.

2 Mahasiswa Magister Ilmu Hukum Universitas Udayana, Denpasar, Bali, e-mail : dikisumadi@gmail. com
} 
usaha bersama berdasarkan asas kekeluargaan. Permasalahan yang dikemukakan dalam penelitian ini adalah, pertama: Bagaimana pengaturan Rekapitalisasi di Dalam Undang-Undang No. 40 Tahun 2007 tentang Perseroan Terbatas? Kedua: Bagaimanakah mekanisme Rekapitalisasi yang ideal dalam mewujudkan asas kekeluargaan dalam Perseroan Terbatas? Penelitian ini menggunakan jenis penelitian hukum normatif yang mengkaji pengaturan mengenai Rekapitalisasi atau penambahan modal dan bagian menimbang huruf c UUPT. Pendekatan yang digunakan untuk memecahkan permasalahan ini adalah pendekatan perundangundangan (the statute approach) dan pendekatan historis (historical approach). Hasil penelitian menunjukkan bahwa, pertama: pengaturan Rekapitalisasi atau penambahan modal ke dalam Perseroan di dalam Undang-Undang No. 40 Tahun 2007 tentang Perseroan Terbatas kurang memadai karena pengaturannya masih memungkinkan akan menimbulkan kerugian bagi pemegang saham minoritas dan tentu saja hal ini bertentangan dengan asas kekeluargaan yang terdapat pada bagian menimbang huruf c Undang-Undang Perseroan Terbatas. Kedua: rekapitalisasi harus dilakukan berdasarkan asas kekeluargaan yaitu melalui jalan musyawarah untuk mufakat, dan tidak menggunakan sistem voting yang lebih menguntungkan pemegang saham mayoritas. Selain hal itu, pemegang saham mayoritas dengan pemegang saham minoritas dapat membuat suatu kontrak yang menyepakati bahwa rekapitalisasi yang akan dilakukan perseroan tidak akan merugikan pemegang saham minoritas, misalnya melalui pemberian saham bonus.

Kata Kunci : Pengaturan, Rekapitalisasi, Perseroan Terbatas.

\section{PENDAHULUAN}

1. Latar Belakang

Dalam kedudukannya sebagai asosiasi modal maka di dalam Perseroan Terbatas terkumpul dan dikelola modal milik para pemegang saham. Modal di dalam perseroan merupakan suatu bagian dari perseroan yang mendasar dan sangat menentukan. Tanpa modal suatu perseroan tidak dapat didirikan dan sudah tentu tidak dapat menjalankan kegiatan usaha serta mewujudkan tujuan didirikannya perseroan. Dari uraian ini tampaklah pentingnya peranan modal dalam perseroan itu.

Sejalan dengan berkembangnya usaha, perseroan dapat mengalami suatu keadaan dimana modal yang ada tidak cukup untuk membiayai usaha-usaha perseroan atau suatu kondisi yang biasanya dikenal dengan kekurangan modal. Kondisi ini apabila dibiarkan dapat menimbulkan dampak negatif terhadap perkembangan perseroan bahkan suatu kebangkrutan. Untuk mencegah dan juga mengatasi hal tersebut, maka perseroan harus melakukan penambahan modal.

$$
\text { Terdapat beberapa cara }
$$
bagi perseroan untuk melakukan penambahan modal antara lain; pertama, melakukan peminjaman modal baik pada bank maupun pada lembaga pembiayaan lain; kedua, mengalihkan aset yang dapat dilakukan 
dengan cara menjual atau menyewakan aset perseroan; dan ketiga, yang akan menjadi topik utama penelitian ini yaitu melakukan rekapitalisasi.

Rekapitalisasi pada pokoknya merupakan suatu kegiatan yang dilakukan dengan tujuan untuk perbaikan struktur dan/atau perubahan jumlah modal yang dilakukan dengan jalan meningkatkan kembali permodalan bank melalui penerbitan saham-saham baru yang dijual, baik kepada para pemegang saham yang sudah ada maupun kepada khalayak umum.

Rekapitalisasi terbagi menjadi dua kegiatan dasar yaitu; Pertama menawarkan saham baru yang diterbitkan oleh perseroan kepada pemegang saham yang sudah ada terlebih dahulu. Sedangkan kegiatan yang kedua adalah apabila pemegang saham yang sudah ada tidak membeli saham yang ditawarkan maka diberikan kesempatan kepada khalayak untuk menjadi pemegang saham baru. Kedua kegiatan tersebut sama-sama bertujuan meningkatkan atau menambah modal perseroan.

Dalam pelaksanaan rekapitali sasi atau penambahan modal baru dalam perseroan terdapat dua subtansi dari Undang-undang Nomor 40 Tahun 2007 tentang Perseroan Terbatas (UUPT) yang harus diperhatikan. Pertama, bagian Menimbang huruf c dinyatakan bahwa perseroan terbatas merupakan salah satu pilar pembangunan perekonomian nasional perlu diberikan landasan hukum untuk lebih memacu pembangunan nasional yang disusun sebagai usaha bersama berdasarkan atas asas kekeluargaan. Kedua, ketentuan-ketentuan mulai dari Pasal 41-43 mengenai penambahan modal.

Permasalahan yang hendak diangkat berkisar pada kesesuaian antara makna yang terkandung dalam Bagian Menimbang huruf c UUPT dengan Pasal 41 sampai dengan Pasal 43 dalam mengatur mengenai rekapitalisasi.

\section{Perumusan Masalah}

Fokus kajian dalam tulisan ini membahas permasalahan sebagai berikut:

1. Bagaimana pengaturan Rekapitalisasi di Dalam Undang-Undang No. 40 Tahun 2007 tentang Perseroan Terbatas?

2. Bagaimanakah mekanisme Rekapitalisasi yang ideal dalam mewujudkan asas kekeluargaan dalam Perseroan Terbatas?

\section{Tujuan Penelitian}

Rekapitalisasi atau penambahan modal Perseroan Terbatas pada intinya merupakan suatu tindakan yang bersifat ekonomis yang dari segi yuridisnya mengakibatkan perubahan struktur permodalan dan hak-hak para pemegang saham Oleh karena itu dapat dikemukakan penelitian terhadap rekapitalisasi perseroan terbatas secara umum mengandung 
tujuan mengembangkan aspek ilmu hukum yang berhubungan dengan ilmu ekonomi.

Adapun tujuan khusus dari penelitian untuk tesis ini adalah untuk mengetahui bentuk pengaturan Rekapitalisasi di dalam UndangUndang Perseroan Terbatas dan untuk mengetahui mekanisme Rekapitalisasi yang ideal dalam mewujudkan asas kekeluargaan dalam Perseroan Terbatas.

\section{METODE PENELITIAN}

Penelitian ini dirancang sebagai penelitian hukum normatif dengan menggunakan pendekatan perundangundangan (statute approach) yaitu pendekatan dengan menggunakan legislasi dan regulasi ${ }^{3}$ dan pendekatan historis (historical approach) yang dilakukan dalam kerangka pelacakan sejarah lembaga hukum dari waktu ke waktu. Pendekatan ini membantu peneliti untuk memahami filosofi dari aturan hukum dari waktu ke waktu. Selain itu peneliti juga dapat memahami perubahan dan perkembangan filosofi yang melandasi aturan hukum tersebut. ${ }^{4}$

Bahan hukumyang dipergunakan dalam penelitian ini terdiri dari Bahan Hukum Primer yaitu bahanbahan hukum yang mengikat ${ }^{5}$, selain itu digunakan juga Bahan Hukum

Peter Mahmud Marzuki, 2005, Penelitian Hukum, Kencana Prenada Group, Jakarta, hlm. 97.

4 Ibid. hlm. 126

5 Soerjono Soekanto dan Sri Mamuji, 1985, Penelitian Hukum Normatif, Suatu Tinjauan Singkat, PT. Raja Grafindo Persada, Jakarta, hlm. 14.
Sekunder yang memberikan penjelasan mengenai bahan hukum primer. ${ }^{6}$ Di samping bahan hukum primer dan bahan hukum sekunder, penelitian ini bersumber pula dari uraian-uraian yang dituangkan dalam bentuk kamus, baik ekonomi maupun hukum.

Bahan-bahan hukum yang digunakan dalam penelitian ini dikumpulkan dari sumbernya dengan mempergunakan metode penelitian kepustakaan (library research). Bahan-bahan hukum yang bersumber dari buku-buku dan tulisan-tulisan atau artikel baik dalam bentuk cetakan maupun elektronik yang relevan dengan penelitian ini dicatat berdasarkan sistem kartu (card system) dan selanjutnya dikutip untuk menunjang penulisan karya tulis ini. Teknik analisis yang digunakan adalah teknik-teknik deskripsi, evaluasi dan argumentasi.

\section{PEMBAHASAN}

\section{Pengaturan Rekapitalisasi Di Dalam Undang-Undang Nomor 40 Tahun 2007}

Pengaturan mengenai rekapitalisasi atau penambahan modal baru sebenarnya sudah dituangkan dalam Perundang-undangan yang mengatur tentang perseroan terbatas. Akan tetapi dalam Kitab Undang-Undang Hukum Dagang (Pasal 26 sampai dengan 56 KUHD) tidak dijumpai pengaturan mengenai penambahan modal. Kendati pun demikian praktek penambahan

Ibid. hlm. 15. 
modal tetap dapat dilaksanakan pada masa itu. Prof. Rochmat Soemitro ${ }^{7}$ mengemukakan penambahan modal dilakukan dengan cara;

a. Memperbesarmodalsecara"reel" dengan jalan menarik uang-uang lagi dari pasar modal dengan emisi saham-saham baru. Dalam hal demikian modal perseroan seperti tercantum pada anggaran dasar harus ditambah dan anggaran dasar harus diubah. Hal ini memerlukan juga pengesahan dari Menteri Kehakiman, dan pula pengumuman seperti pada waktu pendirian;

b. Memperbesar modal nominal dengan tidak menarik bayaran. Pembesaran modal semacam ini lazimnya dilakukan dengan jalan memberikan saham bonus kepada para pemegang saham yang sudah ada, dalam hal ini hanya dapat dilakukan apabila terdapat keuntungan-keuntungan dari tahun-tahun yang lalu tidak dibagikan tetapi dimasukkan dalam cadangan atau jika dilakukan penilaian kembali aktiva yang menunjukkan jumlah yang lebih besar dari pada modal perseroan.

Saham bonus pada dasarnya merupakan saham yang tidak dibayar dengan uang pribadi dari pemegang saham lama. Pembayaran atas saham tersebut diambilkan dari keuntungan-

H. Rochmat Soemitro, 1993, Hukum Perseroan Terbatas, Yayasan dan Wakaf, Eresco, Bandung, hlm. 24 keuntungan yang diraih perseroan. Keuntungan ini tidak dibagikan dalam bentuk deviden melainkan disimpan dalam cadangan. Agar perseroan dapat memberikan saham bonus maka perseroan harus meraih keuntungan dalam beberapa tahun terakhir. Inilah yang merupakan syarat yang cukup berat untuk dilakukannya rekapitalisasi melalui pemberian saham bonus.

Ketentuan yang lebih pasti mengenai penambahan modal baru tertuang dalam Undang-Undang Nomor 1 Tahun 1995 tentang Perseroan Terbatas. Pasal 34 ayat (1) undangundang ini pada pokoknya menentukan bahwa penambahan modal dilakukan berdasarkan keputusan Rapat Umum Pemegang Saham (RUPS). Pasal 36 ayat (1) mengisyaratkan bahwa agar seluruh saham tersebut ditawarkan terlebih dahulu kepada setiap pemegang saham seimbang dengan pemilikan saham untuk klasifikasi saham yang sama.

Penambahan modal perseroan menurut undang-undang perseroan 1995 ini akan menimbulkan suatu konsekuensi terjadinya perubahan terhadap anggaran dasar. Oleh karena itu sahnya keputusan RUPS yang menjadi dasar penambahan modal itu ditentukan harus memenuhi ketentuan mengenai panggilan rapat dan jumlah suara untuk perubahan anggaran dasar (Pasal 35).

Apabila pemegang saham yang sudah ada dalam perseroan tidak menggunakan haknya untuk membeli 
saham yang ditawarkan, maka perseroan dapat menawarkannya kepada karyawan setelah 14 (empat belas) hari. Apabila karyawan tidak juga mengambil tawaran tersebut, maka perseroan dapat menawarkan kepada orang lain (Pasal 36 ayat 2).

Dalam Undang-undang Nomor 40 Tahun 2007 yang merupakan pengganti Undang-undang Nomor 1 Tahun 1995 itu, ketentuan-ketentuan mengenai penambahan modal itu juga sangat singkat atau yang dalam istilah hukumnya disebut dengan "sumir". Sama seperti undangundang sebelumnya, Undang-undang Nomor 40 Tahun 2007 juga hanya menyediakan 3 (tiga) pasal yang tertuang dalam Pasal 41 sampai dengan pasal 43.

Perbandinganpengaturanmengenai rekapitalisasi antara UndangUndang Nomor 1 Tahun 1995 (UUPT lama) dengan Undang-Undang Nomor 40 Tahun 2007 (UUPT baru) yaitu: Pasal 34 UUPT lama yang mengatur mengenaipenambahanmodalperseroan dilakukan berdasarkan persetujuan RUPS mengandung persamaan dengan Pasal 41 UUPT baru. Yang berbeda adalah tentang lamanya waktu yang diberikan kepada Komisaris yang diserahi kewenangan oleh RUPS untuk memberikan persetujuan, Pasal 34 ayat (2) UUPT lama menetapkan 5 (lima) tahun, sedangkan Pasal 41 ayat (2) UUPT baru menetapkan 1 (satu) tahun.

Dalam UUPT baru dilakukan penegasan mengenai Preemptive
Right yaitu pemegang saham 'harus' mendapatkan penawaran terlebih dahulu terhadap saham baru yang akan dikeluarkan dalam rangka penambahan modal tanpa harus diatur atau tidak di dalam anggaran dasar perseroan, sedangkan dalam UUPT lama memperbolehkan anggaran dasar menentukan bahwa saham baru yang dikeluarkan tidak ditawarkan terlebih dahulu kepada pemegang saham yang ada.

Dalam Pasal 36 ayat (2) UUPT lama apabila pemegang saham tidak menggunakan hak untuk membeli saham yang telah ditawarkan maka saham baru tersebut akan ditawarkan terlebih dahulu kepada karyawan perseroan sebelum ditawarkan kepada pihak ketiga, namun dalam UUPT baru apabila pemegang saham tidak menggunakan haknya untuk membeli saham yang telah ditawarkan maka saham itu akan langsung ditawarkan kepada pihak ketiga.

Pasal 43 ayat (3) UUPT baru diatur mengenai pengecualian terhadap Preemptive Right yaitu pemegang saham tidak ditawarkan saham baru yang akan dikeluarkan apabila saham itu ditujukan kepada:

a. ditujukan kepada karyawan Perseroan;

b. ditujukan kepada pemegang obligasi atau efek lain yang dapat di konversikan menjadi saham; atau

c. dilakukan dalam rangka reorganisasi dan/atau restrukturisasi. Pengecualian terhadap Preemp- 
tive Right ini tentu akan merugikan pemegang saham minoritas karena penambahan modal yang dilakukan akan mengakibatkan berkurangnya jumlah saham yang dimiliki oleh pemegang saham minoritas.

Penurunan porsi kepemilikan saham dalam perusahaan ini terjadi akibat adanya pengeluaran saham baru yang merupakan proses dari penambahan modal baru dan saham baru yang dikeluarkan tersebut tidak dibeli oleh pemegang saham yang sudah ada atau saham baru yang dikeluarkan tersebut tidak ditujukan bagi pemegang saham yang telah ada. Sebagai gambaran dari penurunan porsi kepemilikan saham ini adalah:

PT. X terdiri dari 2 orang pemegang saham, yaitu A yang memiliki 40 saham (40\%) dan B memiliki 60 saham (60\%). Suatu ketika PT. X ingin meningkatkan modalnya dengan mengeluarkan 100 saham baru. Jika A dan B tidak menggunakan haknya untuk membeli terlebih dahulu saham baru yang dikeluarkan PT. $\mathrm{X}$ dan yang membeli adalah pihak ketiga, maka persentase kepemilikan A dan B menjadi berkurang. Jika C membeli seluruh saham baru tersebut, maka persentase sahamnya berubah menjadi $\mathrm{A}=20 \%$, $\mathrm{B}=30 \%$, dan $\mathrm{C}=50 \%$.

Kondisi tersebut pada dasarnya merupakan konsekuensi dari pengaturan pelaksanaan penambahan modal perseroan yang didasarkan pada persetujuan RUPS. Sesuai dengan Pasal 84 yang menentukan "setiap saham yang dikeluarkan mempunyai satu hak suara, kecuali anggaran dasar menentukan lain", ini berarti semakin banyak saham yang dimiliki maka semakin banyak pula hak suara yang dimiliki. Dengan perkataan lain pengaturan seperti itu dapat dikatakan menempatkan pemegang saham mayoritas sebagai pemegang kekuasaan yang tertinggi dalam perseroan. Pengaturan yang demikian terlalu memberikan prioritas kepada pemegang saham mayoritas tanpa memperhatikan kondisi dan kemampuan pemegang saham minoritas yang pada umumnya lemah kemampuan finansialnya. Dalam kedudukan sebagai asosiasi orang, maka peranan pemegang saham lain terutama pemegang saham minoritas dalam suatu perseroan tidaklah dapat diremehkan dengan begitu saja. Oleh karena itu perlakuan terhadap pemegang saham minoritas sudah sangat mendesak untuk disesuaikan dengan asas kekeluargaan.

Pengaturan mengenai penambahan modal perseroan yang lebih memihak pemegang saham mayoritas sebenarnya merupakan pengaruh dari pandangan yang pokoknya menyatakan bahwa perseroan terbatas merupakan alat kapitalis.

Milton Friedman ${ }^{8}$ dalam bukunya yang berjudul Capitalism And Freedom sehubungan dengan pembahasan mengenai social

\footnotetext{
8 Milton Friedman, 2009, Social Corporate Responsibility, http://lucidmanager.proves. net, diakses 14 Maret 2015
} 
corporate responsibility menuliskan pandangannya yang kemudian dikenal sebagai The Friedman Doctrine atau Stockholders Theory sebagai berikut: that the primarily responsibility of a business was to increase the profits so that the owners of the firm (stockholders) would earn a higher return.

Berdasarkan hal itu, kewajiban suatu organisasi bisnis adalah meningkatkan keuntungan sehingga pemilik perusahaan (pemegang saham) akan mendapatkan pengembalian yang lebih tinggi. Sudah tentu pemegang saham tunduk pada dalil semakin banyak memegang saham semakin banyak pula keuntungan yang akan diperolehnya.

Ringkasnya pengaturan rekapitalisasi atau penambahan modal baru dalam perseroan pada UUPT ini belum mencerminkan asas kekeluargaan yang ada pada bagian menimbang Undang-Undang tersebut karena dapat melemahkan posisi pemegang saham minoritas.

Asas-asas yang menjadi landasan filosofis suatu peraturan perundangundangan harus dijabarkan ke dalam konsep-konsep yang pasti dan aturanaturan yang rinci. Maka dari itu sudah seharusnya apabila pengaturan rekapitalisasi di dalam UUPT mengacu pada asas kekeluargaan seperti yang dicantumkan pada bagian menimbang huruf c UUPT.
Vol. 5, No. 2 : 219 - 232

http://ojs.unud.ac.id/index.php/jmhu

\section{Rekonstruksi Mekanisme \\ Rekapitalisasi Dalam Menja- barkan Asas Kekeluargaan Pada Perseroan Terbatas}

Perseroan Terbatas merupakan suatu bentuk perusahaan berbadan hukum yang memiliki dua makna yaitu sebagai wadah kerjasama melaksanakan usaha yang saling menghargai, dan sebagai wahana dalam rangka terciptanya Good Corporate Governance (GCG).

Sebagai wadah kerjasama melaksanakan suatu kegiatan usaha terkandung pengertian bahwa dalam perseroan terdapat interaksi dua subyek hukum atau lebih yang diwujudkan dalam perjanjian untuk melakukan suatu perbuatan hukum yaitu mendirikan perseroan terbatas.

Di samping mendirikan perseroan terbatas, kerjasama tadi juga meliputi bidang permodalan. Mengenai siapa saja yang akan menjadi pemodal atau pemegang saham, berapa jumlah saham yang akan diambil dan bagaimana klasifikasi masing-masing saham semuanya harus diperjanjikan diantara para pendiri yang nantinya akan menjadi pemegang saham.

Dalam Pasal 1 angka 1 UUPT menyatakan bahwa perseroan terbatas merupakan badan hukum yang didirikan berdasarkan perjanjian, selain hal tersebut keberadaan perjanjianperjanjian dalam perseroan dapat ditelusuri dari The Nexus of Contract Theory.

Secara umum teori yang awalnya 
dikemukakan oleh Frank Easterbrook itu intinya menjelaskan badan hukum atau korporasi sebenarnya adalah merupakan suatu jaringan yang terdiri dari perjanjian-perjanjian. Berbagai perjanjian yang dimaksud tidak hanya terjadi diantara para pendiri, tetapi melibatkan berbagai pihak.

Perjanjian-perjanjian tersebut terdapat pada 3 (tiga) aspek perseroan terbatas. Pertama aspek pendirian yang meliputi saat awal pendirian perseroan. Aspek kedua adalah menyangkut operasional perseroan dan aspek yang ketiga berkaitan dengan masa-masa berakhirnya perseroan.

Perjanjian-perjanjian yang terdapat pada aspek kedua antara lain meliputi perjanjian ketenagakerjaan, perjanjian dengan supplier, perjanjian dengan pelanggan, perjanjian dengan sesama badan hukum perseroan, dan perjanjian-perjanjian lain yang dibuat pada saat perseroan sudah berdiri serta bersifat operasional.

Perjanjian-perjanjian yang terjadi pada aspek ketiga meliputi 3 (tiga) hal yaitu;

1. perjanjian-perjanjian yang dibuat sehubungan dengan berakhirnya jangka waktu didirikannya perseroan;

2. perjanjian-perjanjian yang dilahirkan setelah perseroan dijatuhi putusan kepailitan;

3. perjanjian-perjanjian yang terbentuk berkaitan dengan perseroan yang berada dalam
Vol. 5, No. $2: 219$ - 232

http://ojs.unud.ac.id/index.php/jmhu

likuidasi.

Keanekaragaman perjanjianperjanjian seperti yang digambarkan berdasarkan The Nexus of Contract Theory itu secara langsung menggambarkan bahwa perseroan sebenarnya juga merupakan wadah kerjasama dua atau lebih subyek hukum yang memiliki tujuan yang sama.

Hubungan yang terjadi diantara pemegang saham mayoritas dan pemegang saham minoritas selain hubungan yang bersifat kontraktual juga hubungan kerjasama pemberi modal perseroan. Dalam perseroan yang didirikan untuk jangka waktu yang relatif panjang sudah sewajarnya perlakuan terhadap mitra tidak hanya didasarkan pada besar-kecilnya modal yang diberikan, tetapi sepatutnya memperhatikan pula martabat pemegang saham minoritas.

Sehubungan dengan makna perseroan sebagai wahana dalam mewujudkan Good Corporate Governance(GCG).GCGadalahsistem pengaturan yang baik terhadap fungsi, tugas, hak dan kewajiban, pengawasan, dan hubungan dari masing-masing dan antara direksi, komisaris, pemegang saham, karyawan, kreditur, investor dan stakeholder lainnya dalam suatau perusahaan perseroan.

Maka dari itu demi terciptanya good corporate governance diberlakukanlah prinsip Mayority Rule Minority Protection, yaitu pihak pemegang saham mayoritas yang 
memiliki kekuasaan dominan dalam pengambilan keputusan perseroan haruslah selalu melindungi kepentingan pihak pemegang saham minoritas. Dalam hal ini pemegang saham minoritas memang perlu diangkat dari keterpurukannya sehingga kepadanya tercapai unsur keadilan sebagaimana yang dipersyartakan dalam Good Corporate Governance.

Prinsip Mayority Rule Minority Protection dikemukakan oleh Munir Fuady dalam bukunya yang berjudul Perlindungan Pemegang Saham Minoritas. Munculnya konsep Mayority Rule Minority Protection ini dikarenakan sifat keputusan yang dibuat oleh pihak pemegang saham mayoritas tidak selamanya adil bagi pemegang saham minoritas, meskipun cara pengambilan keputusan oleh pihak mayoritas itu dianggap paling demokratis. Sebab, dengan sistem putusan mayoritas tersebut, bisa saja seorang yang sudah membiayai perusahaan sampai $48 \%$ dengan memegang saham $48 \quad \%$ dalam hubungan dengan pengendalian dan pengambilan keputusan dalam perusahaan, mereka mempunyai kedudukan yang persis sama dalam pemberian suara dengan pemegang hanya $1 \%$ saham, dan akan sangat berbeda dengan pemegang saham $51 \%$. Maka dari itu untuk menjaga keadilan bagi setiap pemegang saham maka digunakan prinsip 'kekuasaan mayoritas dengan perlindungan minoritas' (Mayority Rule Minority Protection).
Vol. 5, No. $2: 219$ - 232

http://ojs.unud.ac.id/index.php/jmhu

Apabila pemegang saham minoritas dirugikan oleh putusanputusan yang dibuat oleh pemegang saham mayoritas, maka pihak minoritas dapat meminta pengadilan untuk melakukan intervensi ke dalam putusan-putusan yang dibuat oleh pihak mayoritas tersebut. Dengan demikian maka dapat dikatakan bahwa Prinsip Mayority Rule Minority Protection paling mencerminkan asas kekelurgaan yang ada pada bagian menimbang UUPT.

Rekapitalisasi yang baik menurut asas kekeluargaan dan prinsip GCG hendaknya dilakukan dengan cara musyawarah mufakat, sehingga kepentingan pemegang saham minoritas dapat dikemukakan dan dapat dilindungi sedemikian rupa. Pasal 41 ayat (1) UUPT menyebutkan bahwa Penambahan Modal ke dalam Perseroan Terbatas dilakukan berdasarkan persetujuan RUPS. Kemudian pada Pasal 87 ayat (1) UUPT menyebutkan bahwa keputusan RUPS diambil berdasarkan musyawarah untuk mufakat. Pada penjelasannya disebutkan bahwa musyawarah untuk mufakat adalah hasil kesepakatan yang disetujui oleh pemegang saham yang hadir atau diwakili dalam RUPS. Di dalam Kamus Besar Bahasa Indonesia mendefinisikan musyawarah sebagai pembahasan bersama dengan maksud mencapai keputusan atas penyelesaian masalah; perundingan; perembukan. Musyawarah merupakan budaya 
yang tumbuh di dalam masyarakat Indonesia yang telah digunakan oleh rakyat Indonesia sejak dahulu, bahkan musyawarah mufakat merupakan nilainilai asli dari demokrasi pancasila.

Namun dalam praktek RUPS seringkali musyawarah ini dikesampingkan karena sikap pemegang saham mayoritas yang beranggapan bahwa karena ia sudah memberikan modal yang lebih banyak dan memiliki resiko yang lebih besar apabila perusahaan mengalami kerugian maka ia yang lebih berhak untuk mengambil keputusan dalam RUPS. Selain hal tersebut UUPT juga menegaskan sistem one share one vote dalam Pasal 84 ayat (1), hal ini mengakibatkan pemegang saham mayoritas memiliki kewenangan lebih untuk membuat suatu keputusan dalam RUPS dan musyawarah untuk mufakat pun tidak dilakukan dengan baik.

Kurangnya penjabaran mengenai musyawarah di dalam UUPT yang lebih terperinci juga membuat para pemegang saham tersebut tidak serius untukmelakukanmusyawarahmufakat. Muncul anggapan bahwa musyawarah untuk mufakat di dalam RUPS hanya sebuah anjuran yang tidak wajib saja, sehingga para pemegang saham lebih memilih jalur alternatif berupa voting untuk membuat keputusan karena dianggap voting tidak memakan waktu yang lama, dan pembahasan yang bertele-tele.

Musyawarah merupakan salah satu cara yang baik untuk melindungi
Vol. 5, No. $2: 219$ - 232

http://ojs.unud.ac.id/index.php/jmhu pemegang saham minoritas tanpa merugikan kepentingan pemegang saham mayoritas. Dalam hal ini, dengan cara musyawarah tersebut, diharapkan dapat tercapai keseimbangan antara kepentingan pemegang saham mayoritas dan minoritas, sehingga diharapkan dapat terwujud prinsip majority rule minority protection.

Dengan musyawarah diharapkan agar Rekapitalisasi yang dilakukan perseroan tidak mengakibatkan berkurangnya saham yang dimiliki oleh pemegang saham minoritas serta keinginan pemegang saham mayoritas untuk memajukan usahanya dapat dilakukan dengan baik.

$\begin{array}{crr}\text { Cara } & \text { musyawarah } & \text { dalam } \\ \text { pengambilan } & \text { keputusan } & \text { untuk }\end{array}$
melakukan Rekapitalisasi dapat juga ditempuh melalui pembuatan kontrak antar pemegang saham. Kontrak yang dibuat antar pemegang saham mengenai apabila perseroan akan melakukan rekapitalisasi maka cara yang akan ditempuh untuk persetujuan dalam RUPS dan mekanisme Rekapitalisasinya adalah dengan cara musyawarah untuk mufakat, sehingga tidak menimbulkan perselisihan ataupun pihak yang dirugikan dalam Rekapitalisasi tersebut.

Kontrak antar pemegang saham dapat berisikan mengenai pemberian saham bonus bagi pemegang saham minoritas yang tidak mampu membeli saham baru yang ditawarkan. Saham bonus adalah saham yang dibagikan secara cuma-cuma kepada pemegang 
saham sesuai dengan jumlah saham yang dimiliki. Hal ini bertujuan agar jumlah saham yang dimiliki pemegang saham minoritas tidak berkurang secara drastis karena masuknya saham baru.

Kontrak antara pemegang saham agak sulit dibuat karena apabila pihak pemegang saham mayoritas membuat kontrak seperti ini justru akan membatasi dan mengekang hak dan kewenangan yang ia miliki sebagai pemegang saham mayoritas. Namun dalam keadaan tertentu seperti misalnya perseroan memerlukan dana atau fasilitas yang dimiliki oleh pemegang saham minoritas maka ada kemungkinan untuk terealisasikannya kontrak antar pemegang saham mayoritas dengan pemegang saham minoritas. Kontrak antar pemegang saham minoritas ini dapat dilaksanakan sepanjang tidak melanggar Peraturan Perundang-undangan, ataupun melanggar anggaran dasar perseroan. Apabila salah satu pihak tidak melaksanakan kontraknya, maka berlaku hukum tentang wanprestasi secara penuh.

\section{PENUTUP}

\subsection{Simpulan}

1. Pengaturan Rekapitalisasi di dalam Undang-Undang Nomor 40 Tahun 2007 tentang Perseroan Terbatas dijabarkan pada Pasal 41 hingga Pasal 43 mengenai Penambahan Modal. Akan tetapi pengaturan Rekapitalisasi di dalam UUPT ini masih dirasakan kurang melindungi posisi dari pemegang saham minoritas karena keputusan untuk melakukan Rekapitalisasi ditentukan oleh RUPS yang umumnya dikuasai oleh pemegang saham mayoritas, dan pengecualian Preemptive Right pada Pasal 43 ayat (3) UUPT yang akan merugikan pemegang saham karena jumlah saham yang ia miliki akan berkurang karena tidak diberikan kesempatan untuk membeli saham baru yang diterbitkan. Hal ini tentu saja bertentangan dengan asas kekeluargaan yang ada pada bagian menimbang huruf $\mathrm{c}$ UUPT.

2. Mekanisme Rekapitalisasi yang ideal dalam mewujudkan asas kekeluargaan adalah dengan cara musyawarah mufakat. Dengan cara musyawarah mufakat diharapkan keadilan dapat tercipta antara pemegang saham minoritas dengan pemegang saham mayoritas, dan diharapkan apabila kondisi perseroan dalam keadaan darurat untuk segera dilakukan penambahan modal baru, mekanisme musyawarah mufakat agar dilakukan dengan cepat. Selain dengan mekanisme musyawarahmufakat, pembuatan kontrak antara pemegang saham juga merupakan solusi agar asas kekeluargaan terwujudkan dalam rekapitalisasi. Kontrak 
yang dibuat tersebut dapat berupa rekapitalisasi yang akan dilakukan oleh perseroan tidak akan melemahkan posisi pemegang saham minoritas yaitu dengan cara pemberian saham bonus bagi pemegang saham minoritas yang tidak mampu membeli saham baru yang akan diterbitkan.

\subsection{Saran}

1. Sudah seharusnya apabila pengaturan rekapitalisasi di dalam Undang-Undang PerseroanTerbataslebihmengacu pada asas kekeluargaan yang ada pada bagian menimbang huruf $\mathrm{c}$ UUPT. Untuk lebih menjamin kepastian hukum maka disarankan untuk pihak yang terkait agar melakukan suatu pembahasan untuk menyusun suatu pengaturan berupa revisi dalam bentuk penambahan beberapa pasal terhadap Undang-Undang No. 40 Tahun 2007 yang mengatur secara tegas mengenai Rekapitalisasi atau penambahan modal dalam Perseroan, dan melakukan kajian ulang dan menghapus pasal mengenai pengecualian terhadap Preemptive Right yaitu Pasal 43 ayat (3) UUPT, sehingga pihak-pihak yang akan melakukan rekapitalisasi dapat melakukannya dengan baik dan tidak merugikan pihak manapun.

2. Dalam rangka asas kekeluargaan yang mengutamakan prinsip kebersamaan dan saling membantu, ketentuan mengenai pemberian saham bonus perlu dicantumkan lagi dalam Undang-undang Perseroan Terbatas. Dengan memberikan saham bonus yang dibayar dari dividen yang tidak dibagi, pemegang saham minoritas memiliki kesempatan yang sama untuk berpartisipasi dalam penambahan modal perseroan sesuai dengan porsi kepemilikan sahamnya.

\section{DAFTAR PUSTAKA}

\section{Buku}

Ais Chatamarrasjid, 2004, Penerobosan Cadar Perseroan dan SoalSoal Aktual Hukum Perseroan, Citra Aditya Bakti, Bandung.

H. Rochmat Soemitro, 1993, Hukum Perseroan Terbatas, Yayasan dan Wakaf, Eresco, Bandung.

Iman Sjahputra Tunggal dan Amin Widjaya Tunggal, 2002, Membangun Good Corporate Governance, Harvarindo, Jakarta.

Jamin Ginting, 2007, Hukum Perseroan Terbatas (UU No. 40 Tahun 2007), PT. Citra Aditya Bakti, Bandung.

Munir Fuady, 2005, Perlindungan Pemegang Saham Minoritas, CV.Utomo, Bandung. 
Peter Mahmud Marzuki, 2005, Penelitian Hukum, Kencana Prenada Group, Jakarta.

Robert Charles Clark, 1986, Corporate Law, Little, Brownand Company, Boston-Toronto.

Soerjono Soekanto dan Sri Mamuji, 1985, Penelitian Hukum Normatif, Suatu Tinjauan Singkat, PT. Raja Grafindo Persada, Jakarta.

\section{Internet}

Milton Friedman, 2009, Social Corporate Responsibility, http:// lucidmanager.prevos.net, diakses 14 Maret 2015

\section{Peraturan Perundang-Undangan}

Kitab Undang-Undang Hukum Dagang

Undang-Undang Republik Indonesia Nomor 1 Tahun 1995 tentang Perseroan Terbatas.

Undang-Undang Republik Indonesia Nomor 40 Tahun 2007 tentang Perseroan Terbatas. 